\title{
Age and growth of Palaeoloxodon huaihoensis from Penghu Channel, Taiwan: significance of their age distribution based on fossils
}

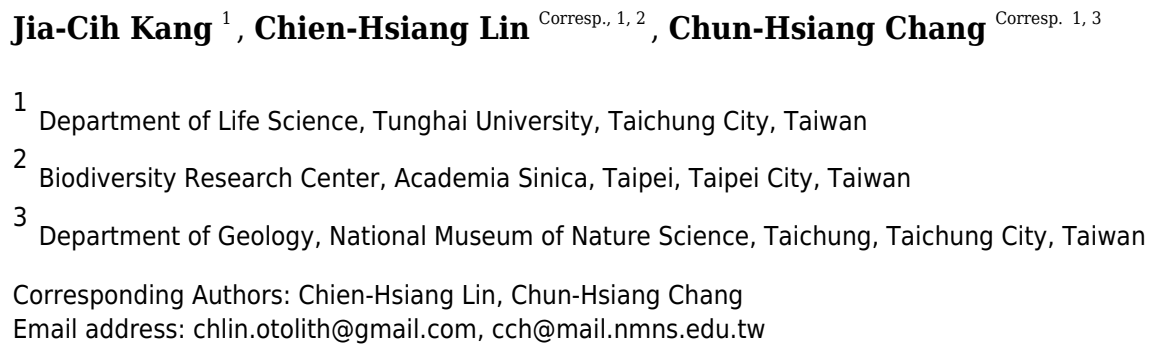

Dental material attributed to Palaeoloxodon huaihoensis from the Middle to Late Pleistocene were recovered over decades from the Penghu Channel during commercial fisheries activities. The National Museum of Nature Science (NMNS) has a collection of such dental material, which differs in size and morphology and likely represents ontogenetic variation and growth trajectory of various age groups of $P$. huaihoensis. However, little is known regarding age determination. By using length of dental material, enamel thickness (ET), and plate counts, we established the method to distinguish the age of the species, which is directly derived from the extant African forest elephant Loxodonta africana. When measuring signs of allometric growth, we found that in both the upper and lower jaws, tooth width was correlated negatively with lamellar frequency but positively with ET. In the same age group, the number of lamellae was higher in $P$. huaihoensis than in $L$. africana. The reconstructed age distribution indicated no difference in the upper or lower jaw. Notably, within our sample, $P$. huaihoensis is skewed towards adult and older individuals with median age between 33-34.5 years and differed significantly from that of Mammuthus primigenius in the European Kraków Spadzista site. This age distribution pattern is speculated to be related to the harsh environmental conditions and intense intraspecific competition among $P$. huaihoensis during the last ice age. 


\section{Age and growth of Palaeoloxodon huaihoensis from}

2 Penghu Channel, Taiwan: significance of their age

3 distribution based on fossils

Jia-Cih Kang ${ }^{1}$, Chien-Hsiang Lin ${ }^{1,2 *}$, Chun-Hsiang Chang ${ }^{1,3^{*}}$

${ }^{1}$ Department of Life Science, Tunghai University, Taichung, Taiwan

${ }^{2}$ Biodiversity Research Center, Academia Sinica, Taipei, Taiwan

Corresponding Author:

Chien-Hsiang Lin ${ }^{2 *}$

Chun-Hsiang Chang ${ }^{3 *}$

Email address:

${ }^{2 *}$ chlin.otolith@gmail.com

$3^{*}$ cch@mail.nmns.edu.tw

Keywords: age distribution, Pleistocene, subtropical West Pacific, elephant age group, lamellar frequency, tooth morphology, Taiwan, Penghu Channel 


\section{Introduction}

43 The fossil genus Palaeoloxodon (Palaeoloxodontinae, Elephantidae) is widely recorded from

44 Eurasia, Africa, and East Asia during the Late Pleistocene (Markiyama, 1924; Matsumoto, 1929;

45 Osborn, 1936; Zong, 1987; Haynes, 1991). Palaeoloxodon has eight known species:

46 Palaeoloxodon antiquus (Falconer \& Cautley, 1847; Osborn, 1942), P. namadicus (Falconer \&

47 Cautley, 1847; Osborn, 1924; Matsumoto, 1929), P. falconeri (Falconer, 1862; Busk, 1867;

48 Vaufrey, 1929; Osborn, 1942), P. mnaidriensis (Adams, 1870), P. cypriotes (Bate, 1903; Osborn

49 1942), P. recki (Dietrich, 1916; Maglio, 1970; Maglio, 1973), P. naumanni (Makiyama, 1924),

50 and P. huaihoensis (Qi, 1999). In China and neighboring areas, fossil records of Palaeoloxodon

51 are relatively abundant (Liu, 1977; Qi, 1999), and many specimens are assigned to $P$. namadicus,

52 P. naumanni or P. huaihoensis (Ho et al., 2000; Shieh et al., 2007; Qi, 1999). Among the three

53 species, $P$. namadicus is found mostly in the Nihewan Basin, China (Wei, 1976). Records of $P$.

54 naumanni are widely distributed in China and Japan but not in Taiwan (Takahashi et al., 2001).

55 Palaeoloxodon huaihoensis is the only known species from the Penghu Channel, Taiwan (Shieh

56 \& Chang, 2007). Ho et al. (2000) stated that $P$. huaihoensis was once distributed both in the

57 China and Taiwan area during the Pleistocene (Shieh \& Chang, 2007).

You et al. (1995) divided the Eastern China Sea into three paleobiogeographic zones in the Late Pleistocene, with the north of $38^{\circ} \mathrm{N}$ representing Mammuthus-Coelodonta fauna, $28^{\circ} \mathrm{N}-38^{\circ} \mathrm{N}$ representing Palaeoloxodon-Elaphurus davidianus fauna, and Ailuropoda-Stegodon fauna to south of $28^{\circ} \mathrm{N}$. According to this scheme, Taiwan and the adjacent Penghu Channel should belong to the Ailuropoda-Stegodon fauna category. However, the Penghu fauna is mainly composed of E. davidianus, Bubalus teilhardi, and P. huaihoensis (Kuo, 1982; Hu \& Tao, 1993; Ho, 1998; Qi, 1999), which is more similar to the fauna in the Huaihe River Region, which belongs to the Palaeoloxodon-E. davidianus fauna (You, 1995; Chen, 2000; Ho et al., 2008). Studies indicate that the existence of a narrow and semiclosed sea similar to a land bridge between the Yellow Sea and East Sea in the last ice age (Chen, 2000). Therefore, the paleoclimate in the Pleistocene Taiwan Strait might belong to the tropical-temperate zone (Cai, 1999). Indeed, the so-called "Taiwan Landbridge Fauna" includes at least two distinct faunas during the Middle-Late Pleistocene: one spanning from the Middle to early Late Pleistocene (Chochen fauna) and one confined to the Late Pleistocene (Penghu fauna) (Chen, 2000).

The fauna of Chochen area includes several large mammals, such as Rhinoceros sinensis hayasakai (Hayasakai, 1942), Stegodon (Parastegodon) akashiensis (Hayasakai, 1942; Shikama et al., 1975; Otsuka, 1984), and Stegodon (Parastegodon) aurorae (Shikama et al., 1975), but no fossils of $P$. huaihoensis were found (Kuo, 1982; Ho \& Qi, 1999). The Chochen fauna is believed to share more affinities with that of the Huanan area in southern China than in with the mammal fauna from northern China (Ho, 1998; Cai, 1999; Ho \& Qi, 1999; Shieh \& Chang, 2007). However, the taphonomic and postmortem transportation processes of Chochen area are

81 very complex and somewhat ambiguous, which resulted in both terrestrial and marine elements

82 in the whole fauna (e.g., Lin et al., 2019). However, the composition of the Penghu fauna 
83 indicates that all of it likely originated from northern China throughout the Pleistocene (Ho et al., 84 1997; Qi, 1999; Shieh \& Chang, 2007).

85

The fossils of elephant teeth provide crucial evidence about the ecosystem in the past. The tooth growth pattern enables inference of the population's age distribution (Haynes, 1985) and the related habitat distribution across vegetation and climate gradient (Webb, 1977; Janis, 1989; Sukumar, 1992; Fox, 2000; Sukumar, 2003). However, previous works on Palaeoloxodon have reported occurrences only, rather than its age distribution. Therefore, this study explored the age distribution and population structure of $P$. huaihoensis from Penghu Channel, Taiwan, using the teeth fossils. We categorized the age groups of $P$. huaihoensis with dental morphological descriptions, reconstructed their age distribution and compared it with other fossil species, and interpreted species distribution in the area.

\section{Materials \& Methods}

\section{Specimens and measurements}

$P$. huaihoensis specimens were all dredged and recovered by bottom trawling from the Penghu Channel, Taiwan, as in Chang (2015). The Penghu Channel $\left(22^{\circ} 40^{\prime} \mathrm{N}-23^{\circ} 40^{\prime} \mathrm{N}, 119^{\circ} 00^{\prime} \mathrm{E}-\right.$ $120^{\circ} 00^{\prime} \mathrm{E}$ ) is located in the Taiwan Strait between Penghu Island (Pescadores) and Taiwan (Fig. 1). A total of 221 teeth (dp4 ( $=3)$, M1 (13), M2 (42), and M3 (163)), including 88 mandibles, were available at the National Museum of Nature Science (NMNS), Taiwan for this study. (Fig. 2, Table S1).

Figure 1: Map showing the sampling area in the Penghu Channel (dashed rectangle). The base map was created using ArcGIS.

Figure 2: Images of $P$. huaihoensis specimens deposited at the National Museum of Nature Science (NMNS). (A) Nine enamel loops complete of the lower left dp4 and erosion at both ends, F027933. (B) All lamellae in wear and the lower right M1 is connected to M2, which is slightly worn and lacks enamel thickness (ET), F020284. (C) Nineteen lamellae of the lower left M3 in buccal view, F051590. (D)(E) The upper right and left M3 with all lamellae in wear and slightly eroded at both ends, F026947. (F) Buccal surface of the lower right M3, F020284. (G) Anterior 2-3 enamel loops confluent on the occlusal surface of lower right M3 from catalog number F020226. (H) Lingual view of the lower right M3, F020248. All scale bars represent 5 $\mathrm{cm}$.

We first used the plate counts to identify the dental position of the molar. Next, the tooth length, width, and height were measured (Fig. 3), with the height taken vertically from the crown apex of the plate. The enamel thickness (ET) was measured with calipers. To calculate lamellar frequency, the number of complete plates at $10 \mathrm{~cm}$ at the crown base of both the lingual and buccal sides was taken (Short, 1969; Hasegawa, 1972; Maglio, 1973; Shieh \& Chang, 2007). 
124 Figure. 3. Measurements of an elephant tooth used in this study. (A) The length of dental

125 material and width were measured. (B) The height of tooth was taken from the crown apex of the 126 highest plate to the crown base on both the lingual and buccal sides.

127

128

129

130

131

132

133

134

135

136

137

\section{Age determination}

We used the size, wear of teeth and dental morphology to determine the age distribution of $P$. huaihoensis (Morrison-Scott, 1947; Sikes, 1966; Maglio, 1973; Lang, 1980). Thirty age groups based on tooth morphology and shearing rate of deciduous teeth of African forest elephants were established by Laws (1966), and this method has been widely used for the reconstruction of age distribution in many elephant species (Haynes, 1991; Lister, 1999). We used this method too with slight modifications. For example, Laws' method indicates that M3 has a maximum number of 12 plates in L. africana, but in P. huaihoensis, as many as 22 plates can be found in M3. In this case, the remaining number of plates in $P$. huaihoensis can be obtained by the rate of tooth eruption of $L$. africana multiplied by the observed plates of $P$. huaihoensis. Thus, the age group XX of Law's with 12 plates indicates that there will be six plates in the age groups of $P$. huaihoensis if $(22 / 12) \times 6=11$ plates are remaining (see Table S2). The rate of tooth eruption of L. africana represent the value of ratio that expect the appeared number of plates of $P$. huaihoensis. Consequently, we established 24 age groups defined using 88 jaws (Fig. 4).

Figure 4: Definition of age groups I-XXIV. I: dp4 all lamellae in wear, M1 slight wear (specimen number: F02793); II: dp4 well worn, approximately 3-4 plates remaining; M1 first 1-2 lamellae in wear (F051613); III: M1 all in wear; M2 worn to enamel of first two lamellae (F044264); IV: M1 first 1-2 enamel loops confluent, M2 slight wear (F020284); V: M1 well worn; M2 more enamel loops showing (F051497); VI: M1 only 5-6 enamel loops left, slight erosion of posterior border; M2 lamellae well formed (F051562); VII: M1 well worn, only three plates remain; M2 slight erosion of anterior edge, 9-10 enamel loops complete (F027950); VIII: M2 first enamel loops confluent (F044271); IX: M1 worn out; M2 well into wear showing lozenges, more lamellae visible (F020247); X: M2 all except last 3 lamellae in wear (F020255); XI: M2 complete, all lamellae in wear, and all enamel loops showing M2 erosion at both ends; M3 lamellae well formed (F027988); XII: M2 all lamellae in wear, 15 enamel loops complete (F026927); XIII: M2 only approximately 8-9 loops remain and erosion at both ends (F020287); XIV: M3 worn to enamel of first lamellae and more enamel loops (F030111); XV: M2 lost; M3 11-12 enamel loops complete (F020278); XVI: M2 worn out; M3 no erosion of anterior border, anterior 1-2 enamel loops confluent (F044257); XVII: M3 only 2 lamellae not in wear (F027320); XVIII: M3 all except last lamellae in wear (F044266); XIX: M3 first 1-2 enamel loops may confluent (F051487); XX-I: M3 erosion at both borders, anterior 2-3 enamel loops confluent (F026942); XX-II: M3 all except last lamellae in wear (F020258); XXI-I: M3 more enamel loops showing, slight erosion of the anterior border (F044270); XXI-II: M3 well worn, first enamel loops may be slightly confluent (F051560); XXII-I: M3 all lamellae in wear, no erosion at both ends (F044268); XXII-II: M3 erosion at both borders, anterior 2-3 enamel loops confluent (F027963); XXIII-I: M3 only five complete enamel loops remain, anterior part broken off (F044261); XXIII-II: anterior third of tooth missing, only five complete lamellae remain (F027967); XXIV: M3 only 2-3 loops remain (F051559). 


\section{Statistical analysis}

169 The tooth width and lamellar frequency in occlusal and buccal sides of the lower and upper jaws

170 of dp4-M3 as well as the relationship between the width and enamel thickness (ET) of lower and 171 upper jaws of dp4-M3 were plotted using R software (Core Team and Others 2013). The

172 relationship between two variables was indicated using Pearson's correlation coefficient. These

173 relationships reflect whether the concerned variables revealed an allometric growth pattern. The

174 number of lamellae throughout the lifespan was plotted against the estimated age of $P$.

175 huaihoensis (see above, Age determination), and these were directly compared with those of $L$.

176 africana (Laws, 1966).

A histogram based on the frequency distribution of specimens was established to reconstruct the age distribution of $P$. huaihoensis. Unlike studies in which only the lower mandibles were considered (Laws, 1966), we included upper mandibles specimens for comparison. A null hypothesis of the distributions of upper and lower jaws was first tested using the two-sample $t$ test. However, when no significant difference between upper and lower mandibles was detected, only lower jaw specimens were used in subsequent analyses. A Shapiro-Wilk test was conducted to test whether the fossil age distribution data were distributed normally; if not, the median for the lower jaws was calculated using the Wilcoxon-Mann-Whitney test.

Finally, we compared the age distribution based on fossil remains of $P$. huaihoensis with other species: the stable age distribution of fossil Mammuthus primigenius and M. columbi. A null hypothesis stating the same age distribution for each population pair was analyzed using Pearson's chi-square test. Here, the independence of age and the number of individuals in each of the two populations were tested. The M. columbi and M. primigenius data were derived from the studies of Louguet-Lefebvre (2013) and Wojtal (2001), respectively. All analyses were performed using R (Core Team and Others 2013).

\section{Results}

196 Tooth width and lamellar frequency were negatively correlated on both the occlusal and buccal sides for dp4-M3. Lamellar frequency increased when tooth width decreased in both upper and lower jaws (Fig. 5a, b, d, e). By contrast, the tooth width and ET were positively correlated on both the sides (Fig. 5c, f). The size range overlapped in some cases; for instance, the M2 overlapped with M3 in occlusal width and lamellar frequency and width and ET of the lower jaw, respectively (Fig. 5d, f).

Figure 5: The relationships of various meristic measurements in the jaws of dp4-M3.

(A) Tooth width and lamellar frequency in the occlusal surface of the upper jaw $(\mathrm{r}=-0.558, \mathrm{t}=$ $-7.699, \mathrm{p}<0.05$ ). (B) Tooth width and lamellar frequency in the buccal side of the upper jaw ( $\mathrm{r}$ $=-0.476, \mathrm{t}=-6.201, \mathrm{p}<0.05)$. (C) Tooth width and enamel thickness (ET) of the upper jaw ( $\mathrm{r}=$ $0.531, \mathrm{t}=7.179, \mathrm{p}<0.05)$. (D) Width and lamellar frequency in the occlusal surface of the lower jaw $(\mathrm{r}=-0.649, \mathrm{t}=-7.915, \mathrm{p}<0.05)$. (E) Width and lamellar frequency in the buccal side of the 
209 lower jaw $(\mathrm{r}=-0.453, \mathrm{t}=-7.523, \mathrm{p}<0.05)$. (F) Width and ET of the lower jaw $(\mathrm{r}=0.457, \mathrm{t}=$ $2104.759, \mathrm{p}<0.05)$.

211

A summary of the various age groups derived from the tooth morphology, lamellar number, teeth position, and age estimation is presented in Table 1. The number of lamellae of $P$. huaihoensis was considerably higher than that of L. africana in the same age group (Fig. 6). Moreover, the increasing rate of lamellae in $P$. huaihoensis was progressively more evident than that of $L$. africana from M1, eventually reaching 22 lamellae in M3.

Table 1: Comparison of estimated ages derived from the lower jaw of $P$. huaihoensis and $L$. africana. The positions of the teeth used in Laws (1966) are indicated in parentheses.

Figure 6: Differences in the relationship of the number of lamellae and age in P. huaihoensis and L. africana. Data of L. africana are from Laws (1966).

The reconstructed age distribution of $P$. huaihoensis revealed that the age peaked at 29-36 years, indicating a higher number of adult individuals (Fig. 7). Notably, the distributions of the upper and lower jaws were similar (two-sample $t$ test, $p=0.941, t=0.075$ ), and they possibly originated from a single population (mean $=0.04$ ). The Shapiro-Wilk test indicated a nonnormal age distribution $(\mathrm{p}<0.05)$, and using the Wilcoxon-Mann-Whitney test, the medians of lower jaws indicated an age of 33-34.5 years.

230

Figure 7: Age distribution of $P$. huaihoensis from Penghu Channel, Taiwan. The frequency (\%)

Pearson's chi-square test revealed that $P$. huaihoensis age distribution was significantly different from the stable age distribution of M. primigenius ( $<<0.05$, Fig. 8a) but not from that of $M$. columbi ( $\mathrm{p}>0.05$, Fig. 8 b). M. primigenius mainly comprised juveniles and young-adult individuals, whereas $P$. huaihoensis and $M$. columbi comprised mostly adults aged 30-40 years.

\section{Discussion}

240 Tooth eruption has widely been used for estimating extant elephant age (Laws, 1966; Krumery \& 241 Buss, 1968; Shoshani, 1982; Roth \& Shoshani, 1988). This method has also been applied to 242 fossil species - for example, the age distribution of the Mammut (Mastodon) (Haynes, 1985), M. 243 columbi (Saunders, 1980; Louguet-Lefebvre, 2013), and M. primigenius (Lister, 1999; Wojtal, 244 2001; Rountrey, 2012). However, in P. huaihoensis, plate count, length, ET, and lamellar 245 frequency measurements revealed substantial differences from the extant $L$. africana (e.g., Fig. 246 6).

248 Our age distribution for $P$. huaihoensis has a distinct pattern compared with that of $M$. 249 primigenius (Wojtal, 2001). In M. primigenius, numerous younger individuals (0-12 years) and 
250 fewer adults were found in the European Kraków Spadzista site (Fig. 8a). The pattern of $M$.

251 primigenius represents the natural deaths of the whole population, suggesting nonselective

252 cumulative deaths in the normal environment (Klein, 1985; Haynes, 1991; Haynes \& Klimowicz,

253 2016).

254

255 Figure 8: Comparison of the age distribution of $P$. huaihoensis with that of (A) M. primigenius 256 and (B) M. columbi.

257

258 Although the upper and lower jaws of $P$. huaihoensis suggest that these specimens originate 259 from a single population, the reconstructed age distribution indicates an older adult-dominant

260 pattern (median $=33-34.5$ years). The age profile of $P$. huaihoensis seems to be similar to that of

261 M. columbi (Fig. 8b), but the living environment and taphonomic process for both species were

262 completely disparate. The Hot Springs site has yielded many specimens of $M$. columbi, and this

263 site was not only essential for providing a water source for animals inhabiting adjacent areas but

264 also a natural trap with unstable sediments that preferentially traps larger adult individuals

265 (Agenbroad \& Mead, 1994). This may be the reason that the inferred M. columbi population

266 mainly comprised adult individuals (Louguet-Lefebvre, 2013). Intense intraspecific competition

267 between adults under harsh environmental conditions can cause massive death; we speculate that

268 this was one of the possible cases of $P$. huaihoensis. During the last ice age, climate change-

269 related resource shortages likely resulted in sharp competition within the population of $P$.

270 huaihoensis, particularly in large adult males (Valeix et al., 2007; Ferry et al., 2016).

271

272

In addition to competition, the notable older age predominance may have been caused by

273 sampling bias because our materials were collected by bottom trawl fisheries and smaller teeth of $P$. huaihoensis from younger individuals may not have been sufficiently represented. However, fossils from the Penghu Channel have been collected for decades and have resulted in a massive collection of a diverse fauna (e.g., Hu \& Tao, 1993), including fossil remains of much smaller sizes such as fragments of the tibia, vertebrae, ribs, and even a tiny lower jaw of Homo (Chang et al., 2015) were recovered using this method. In any case, small teeth of $P$. huaihoensis would be considerably represented if they existed. Therefore, the age frequency distribution suggests that the area around Penghu Channel might not have been a nursery ground for $P$. huaihoensis. Nevertheless, whether our material represents an equilibrium age distribution of $P$. huaihoensis remains uncertain because this age distribution could have existed only in fossil species. The fossil records of P. huaihoensis date from the Middle to Late Pleistocene (Liu, 1977; Chen, 2000). The species was first found in the northern part of Anhui, China (Liu, 1977). The further geographical distribution includes Huaihe River Region (Cai, 1999; Ho \& Qi, 1999) and northern Jiangsu, China (Qian, 2017; Chen et al., 2020) (Fig. 9). In Taiwan, however, the species has only been found in the Penghu Channel and never southwards; thus, it is not found in the famous Chochen fauna (Kuo, 1982). Because of cold temperatures and water and food shortage, animals could have migrated from higher to lower latitudes; in particular, $P$. huaihoensis could 
290 have migrated southward in search of grasslands and water resources (Webb, 1977; Janis, 1989;

291 Fox, 2000). However, possible ecological explanations, such as climate change and niche

292 competition, have yet to be explored fully. On the other hand, this age distribution-that rare

293 young but adult dominated-is not that uncommon among proboscideans (see Green \& Hulbert

2942005 on mastodons), and it may well be possible that there are a number of causes that could

295 independently lead to this age structure. For example, the differences between the age-related

296 populations of M. columbi at Hot Springs, M. primigenius in the European Kraków Spadzista

297 site, and $P$. huaihoensis from Penghu Channel, could also due to unrecognizable time averaging

298 effect. Overall, the fossil records suggest that $P$. huaihoensis was distributed from northern

299 China and to as far south as Penghu Channel in the last ice age but did not migrate across the

300 Taiwan Strait to Taiwan Island (Fig. 9).

301

302

303

304

Figure 9: Postulated migration direction (black arrow) of $P$. huaihoensis. The species likely originated from northern China (white circle), where fossil records are more abundant. The extension of the record in the Penghu Channel (black rectangle) in the last ice age is currently its southern limit. The current sea depth contour $(-120 \mathrm{~m})$ delineates the ancient coastline during the last ice age. The map is derived from the National Centers for Environmental Information (https://www.ngdc.noaa.gov).

\section{Conclusions}

The age distribution of such a large mammal as $P$. huaihoensis, which once inhabited the subtropical west Pacific in the Late Pleistocene, has been largely unknown. By using its dental material from the Penghu Channel, we reconstructed its age distribution and defined 24 age groups by measuring the ontogenetic morphological changes in teeth length, ET, and plate counts. Compared with $M$. primigenius, $P$. huaihoensis from the Penghu Channel is distinct in having significantly more adult and older adult individuals and very few juveniles, similar instead to M. columbi. However, unlike taphonomic patterns of age distribution observed in the case of $M$. columbi, we speculate that environmental conditions and intraspecific competition are several of the possible causes. The fossil records further indicate that $P$. huaihoensis was mainly distributed in northern China and only extended southward in the Penghu Channel. The postulated ancient migration route of the species and the possible underlying ecological reasons would benefit from further investigation of the collection from northern China. Future studies should elucidate the exact age distribution of $P$. huaihoensis in northern China compared with that of the Penghu Channel and conduct isotope analyses to explore the possible vegetation and climatic impacts on the migration and specific age distribution recovered from the Penghu Channel.

\section{Acknowledgements}

We are grateful to Prof. Yi-Ching Lin (Department of Life Science, Tunghai University, Taiwan) and Xinyue Ou (Tunghai University, Taiwan) for their constructive comments and suggestions on the statistical analyses. 


\section{References}

333 Adams AL. 1870. Notes of a Naturalist in the Nile Valley and Malta: a narrative of exploration

334 and research in connection with the natural history, Geology and archaeology of the lower Nile and Maltese Islands. Edinburgh, UK: Edmonston and Douglas. 295 Agenbroad LD, Mead JI. 1994. The Hot Springs Mammoth Site: a Decade of Field and Laboratory Research in Paleontology, Geology, and Paleoecology, Mammoth Site of Hot Springs. South Dakota, Inc., Hot Springs. 451 DOI: 10.1086/419383 Bate DMA. 1903. Preliminary note on the discovery of a pygmy elephant in the Pleistocene of Cyprus. Proceedings of the Royal Society of London B197:347-60 Busk G. 1867. Description of the remains of three extinct species of elephant, collected by Capt. Spratt, C. B. R. N., in the ossiferous cavern of Zebbug, in the island of Malta. Partly from the notes from the late H. Falconer, M. D. F. R. S. Transactions of the Zoological Society of London VI (PtV) 227-306 Cai BQ. 1999. The Later Pleistocene Fossil Mammals and the Palaeogeographical Environment of the Taiwan Strait. Journal of Xiamen University (Arts \& Social Sciences) 4:29-33 Chang CH, Kaifu Y, Takai M, Kono RT, Grün R, Matsu'ura S, Kinsley L, Lin LK. 2015. The first archaic Homo from Taiwan. Nature Communications 6:6037 DOI: 10.1038/ncomms7037 Chen X, Wu S, Wang P, Wang XB, Chao JH. 2020. A report on the Late Pleistocene vertebrate fossils from the Zhangshan locality, Suqian, Jiangsu Province. Acta Antheropologica Sinica 39(2):319-331 DOI: 10.16359/j.cnki.cn11-1963/q.2018.0021

Chen KT. 2000. On Taiwan Mammalian Faunas in Different Periods of Time and Related Problems: The Background Materials for Taiwan Zooarchaeological Studies: I. Bulletin of the Institute of History and Philology Academia Sinica 71(1):129-198 Dietrich WO. 1916. Elephas antiquus Recki n.f. aus dem Diluvium Deutsch- Ostafiikas. Archives of Biology $4: 1-80$

357 Falconer H, Cautley PT. 1847. Fauna Antiqua Sivalensis, being the Fossil Zoology of the Sewalik Hills in the North of India. London: Smith, Elder and Co. Falconer H. 1862. On Ossiferous Caves in Malta, Explored by Captain Spratt, R.N., C.B., with an account of Elephas meletensis, a pigmy species of fossil elephant and other remains found in 361 them. Parthenon 125:780

362 Fatti LP, Smuts GL, Starfield AM, Spurdle AA. 1980. Age Determination in African Elephants. Journal of Mammalogy 61(3):547-551 DOI: 10.2307/1379852

364 Ferry N, Dray S, Fritz H, Valeix M. 2016. Interspecific interference competition at the resource patch scale: do large herbivores spatially avoid elephants while accessing water? Journal of Animal Ecology 85(6):1574-85 DOI: 10.1111/1365-2656.12582

367 Green JL, Hulbert Jr. RC. 2005. The deciduous premolars of Mammut americanum (Mammalia, Proboscidea). Journal of Vertebrate Paleontology 25:702-715 
369 Hasegawa Y. 1972. The Naumann's elephant, Palaeoloxodon naumanni (MAKIYAMA) from

370 the late Pleistocene off Shakagahana, Shodoshima Is. In Seto Inland Sea, Japan. Bulletin of the

371 National Science Museum 15(3):513-591

372 Hayasakai A. 1942. On the occurrence of mammalian remains in Taiwan - a preliminary

373 summary. Taiwan Tigaku Kizi 13(4):95-109

374 Haynes G. 1985. Age Profiles in Elephant and Mammoth Bone Assemblages. Quaternary

375 Research 24(3):333-345 DOI: 10.1016/0033-5894(85)90055-9

376 Haynes G. 1988. Longitudinal studies of African elephant death and bone deposits

377 Journal of Archaeological Research 15:131-157

378 Haynes G. 1991. Mammoths, Mastodons, and Elephants: Biology, Behavior, and the Fossil

379 Record. New York: Cambridge University Press. 413 DOI: 10.1002/gea.3340090506

380 Haynes G, Klimowicz J. 2016. The Meaning of the Mammoth Age Profile from Kraków

381 Spadzista Trench B+B1. In Wojtal P, Wilczynski J, Haynes G. (Eds.), A Gravettian Site in

382 Southern Poland: Kraków Spadzista. Institute of Systematics and Evolution of Animals, Polish

383 Academy of Sciences, Kraków.

384 Ho CK, Qi GQ, Chang CH. 1996. A preliminary study and reconstruction of Late Pleistocene

385 megafauna Bubalus teilhardi Young from the Penghu Channel. Taiwan Annual of Taiwan

386 Museum 39:1-15

387 Ho CK, Qi GQ, Chang CH. 1997. A Preliminary Study of Late Pleistocene Carnivore FossiIs

388 from the Penghu Channel, Taiwan. Journal of the National Taiwan Museum 40:195-224 DOI:

$389 \quad 10.6548 / \mathrm{ATMB}$

390 Ho CK. 1998. The mammalian of Penghu Channel in the Late Pleistocene. Newsletter of Chinese

391 Ethnology 36:3-11

392 Ho CK, Qi GQ. 1999. Quaternary fauna and paleoenvironment of Penghu submarine trench of

393 Taiwan. Quaternary Science 2:47-48

394 Ho CK, Qi GQ, Chang CH. 2000. Systematic Description and Classification of Late Pleistocene

395 Palaeoloxodon. Journal of the National Taiwan Museum 43:49-105 DOI:

396 10.6548/ANTM.200012 43.0003

397 Ho CK, Qi GQ, Chang CH. 2008. A preliminary study of Late Pleistocene Megafauna Cervus sp.

398 from the Penghu Channel, Taiwan. Journal of Taiwan Museum 61(1):1-16 DOI: 10.6532/JNTM

$399 \mathrm{Hu}$ CH, Tao HJ. 1993. The fossil faunas of Penghu Islands, Taiwan. Taiwan, Penghu: Penghu

400 District Cultural Center Publications.

401 Janis CM. 1989. A climatic explanation for patterns of evolutionary diversity in ungulate

402 mammals. Palaeontology. 32: 463-481

403 Klein RG. 1985. Age (mortality) profiles as a means of distinguishing hunted species from

404 scavenged ones in Stone Age archeological sites. Paleobiology 8(2):151-158

405 Krumery WA, Buss IO. 1968. Age estimation, growth, and relationships between body

406 dimensions of the female African elephant. Journal of Mammalogy 49:22-31 DOI:

$407 \quad 10.2307 / 1377724$

408 Kuo YW. 1982. Penghu fauna. Journal of Marine Science 27:123-132 
409 Lang EM. 1980. Observations on growth and molar change in the African elephant. African

410 Journal of Ecology 18:217-234 DOI: 10.1111/j.1365-2028.1980.tb00643.x

411 Laws RM. 1966. Age criteria for the African elephant. The East African Wildlife Journal 4:1-37

412 DOI: $10.1111 / \mathrm{j} .1365-2028.1966 . t b 00878 . \mathrm{x}$

413 Lin CH, Chien CW, Lee SW, Chang CW. 2019. Fish fossils of Taiwan: a review and

414 prospection. Historical Biology DOI: 10.1080/08912963.2019.1698563

415 Lister AM. 1999. Epiphyseal fusion and postcranial age determination in the woolly mammoth,

416 Mammuthus primigenius (Blum.). Deinsea 6:79-88

417 Liu JL. 1977. Palaeoloxodon from Huaiyuan District, northern part of Anhui. Vertebrata

418 PalAsiatica 15(4):278-286 DOI: $10.19615 /$ i.cnki.1000-3118.1977.04.006

419 Louguet-Lefebvre S. 2013. The Columbian mammoths from the Upper Pleistocene of Hot

420 Springs (South Dakota, United States). PALEO 24:149-171 DOI: doi.org/10.4000/paleo.2861

421 Maglio VJ. 1970. Early Elephantidae of Africa and tentative correlation of African Plio-

422 Pleistocene deposits. Nature 225:328-332

423 Maglio VJ. 1973. Origin and evolution of the Elephantidae. Transactions of the American

424 Philosophical Society, New Series 63:1-149 DOI: $\underline{10.2307 / 1006229}$

425 Makiyama J. 1924. Notes on a fossil elephant from Sahama, Totomi. Memoirs of the College of

426 Science. Kyoto Imperial University. Series B. Biology 1(2):255-264

427 Matsumoto H. 1929. On Loxodonta (Palaeoloxodon) tokunagai MATSUMOTO, with remarks

428 on the descent of Loxodontene elephants. Science reports of Tohoku University. Series, 2

429 (Geology) 13(1):7-9

430 Morrison-scott TCS. 1947. A revision of our knowledge of African elephants' teeth, with notes

431 on forest and 'pygmy' elephants. Proceedings of the Zoological Society of London 117:505-527

432 DOI: $\underline{10.1111 / \mathrm{j} .1096-3642.1947 . t b 00534 . x}$

433 Osborn HF. 1936. Proboscidea: a monograph on the discovery, evolution, migration and

434 extinction of the mastodonts and elephants of the world. Moeritherioidea, Deinotherioidea,

435 Mastodontoidea, Volume I. New York: The American Museum Press. 864

436 Osborn HF. 1942. Proboscidea: a monograph of the discovery, evolution, migration and

437 extinction of the mastodonts and elephants of the world. Stegodontoidea, Elephantoidea, Volume

438 II. New York: American Museum of Natural History. 958

439 Otsuka H. 1984. Stratigraphic position of the Chochen vertebrate Fauna of the Chochen District,

440 southwest Taiwan, with special reference to its geologic age. Journal of the National Taiwan

441 Museum 37(1):37-55

442 Qian MP, Gao TS, Jiang R, Zhu QB, Jin GD, Yu JJ, MA X, Jiang Y. 2017. The discovery of a

443 late Pleistocene Palaeoloxodon huaihoensis skeleton from Sihong County in northern Jiangsu

444 Province. Journal of Stratigraphy 41(2):173-178

445 Roth VL, Shoshani J. 1988. Dental identification and age determination in Elephas maximus.

446 Journal of Zoology (London) 214:567-588 DOI: 10.1111/j.1469-7998.1988.tb03760.x 
447 Rountrey AN, Fisher DC, Tikhonov AN, Kosintsev PA, Lazarev PA, Boeskorov G, Buigues B. 448 2012. Early tooth development, gestation, and season of birth in mammoths. Quaternary

449 International 255:1-10 DOI: 10.1016/j.quaint.2011.06.006

450 Shieh YT, Chang CH. 2007. Study on the Proboscidea Fossils of the National Taiwan Museum.

451 Journal of Taiwan Museum 60(1):33-44 DOI: 10.6532/JNTM

452 Short RV. 1969. Notes on the teeth and ovaries of an African elephant (Loxodonta africana) of

453 known age. Journal of Zoology (London) 158:421-425 DOI: 10.1111/j.1469-

454 7998.1969.tb02159.x

455 Shikama T, Otsuka H, Tomida Y. 1975. Fossil Proboscidea from Taiwan (I). Science reports of

456 the Yokohama National University, Section II, Biological and geological sciences 22:13-35

457 Sikes K. 1967. The African elephant, 22: a field method for estimating age. The Journal of

458 Zoology 154:235-248 DOI: 10.1111/j.1469-7998.1968.tb01661.x

459 Sukumar R. 1992. The Asian Elephant: Ecology and Management. Cambridge studies in applied

460 ecology and resource management. Cambridge: Cambridge University Press. 272

461 - 2003. The living elephants: Evolutionary ecology, behavior, and conservation. New York:

462 Oxford University Press. 496

463 Takahashi K, Namatsu K. 2000. Origin of the Japanese Proboscidea in the Plio-Pleistocene.

464 Earth Science (Chikyu Kagaku) 54(4):257-267 DOI: 10.15080/agcjchikyukagaku.54.4_257

465 Valeix M, Chamaillé-Jammes S, Fritz H. 2007. Interference competition and temporal niche

466 shifts: elephants and herbivore communities at waterholes. Oecologia 153:739-748 DOI:

$467 \quad 10.1007 / \mathrm{s} 00442-007-0764-5$

468 Vaufrey R. 1929. Les éléphants nains des iles méditerranéennes et la question des isthmes

469 Pléistocènes. Archives de TInstitut de Paléontologie Humaine, Paris 6:1-216

470 Webb, S.D., 1977. A history of savanna vertebrates in the new world — Part 1: North America.

471 Annu. Annual Review of Ecology and Systematics. 8:355-380

472 Wei Q. 1976. Recent find of Palaeoloxodon namadicus from Nihewan Beds, NW Hebei.

473 Vertebrata PalAsiat 14:53-58

474 Wojtal P. 2001. The woolly mammoth (Mammuthus primigenius) remains from the Upper

475 Palaeolithic site Krakow Spadzista Street (B). Proceedings of the 1st International Congress.

476 CNR, Rome 367-372

477 You YZ, Dong XR, Cai BQ, Sun YL. 1995. The mammalian fossils from western Taiwan strait.

478 Vertebrata PalAsiat 33(3):231-237

479 Zong G. 1987. Note on some mammalian fossils of Yanyuan, Sichuan. Vertehrata PalAsiatica

480 25(2):137-45 
Figure 1

Map showing the sampling area in the Penghu Channel (dashed rectangle). The base map was created using ArcGIS.

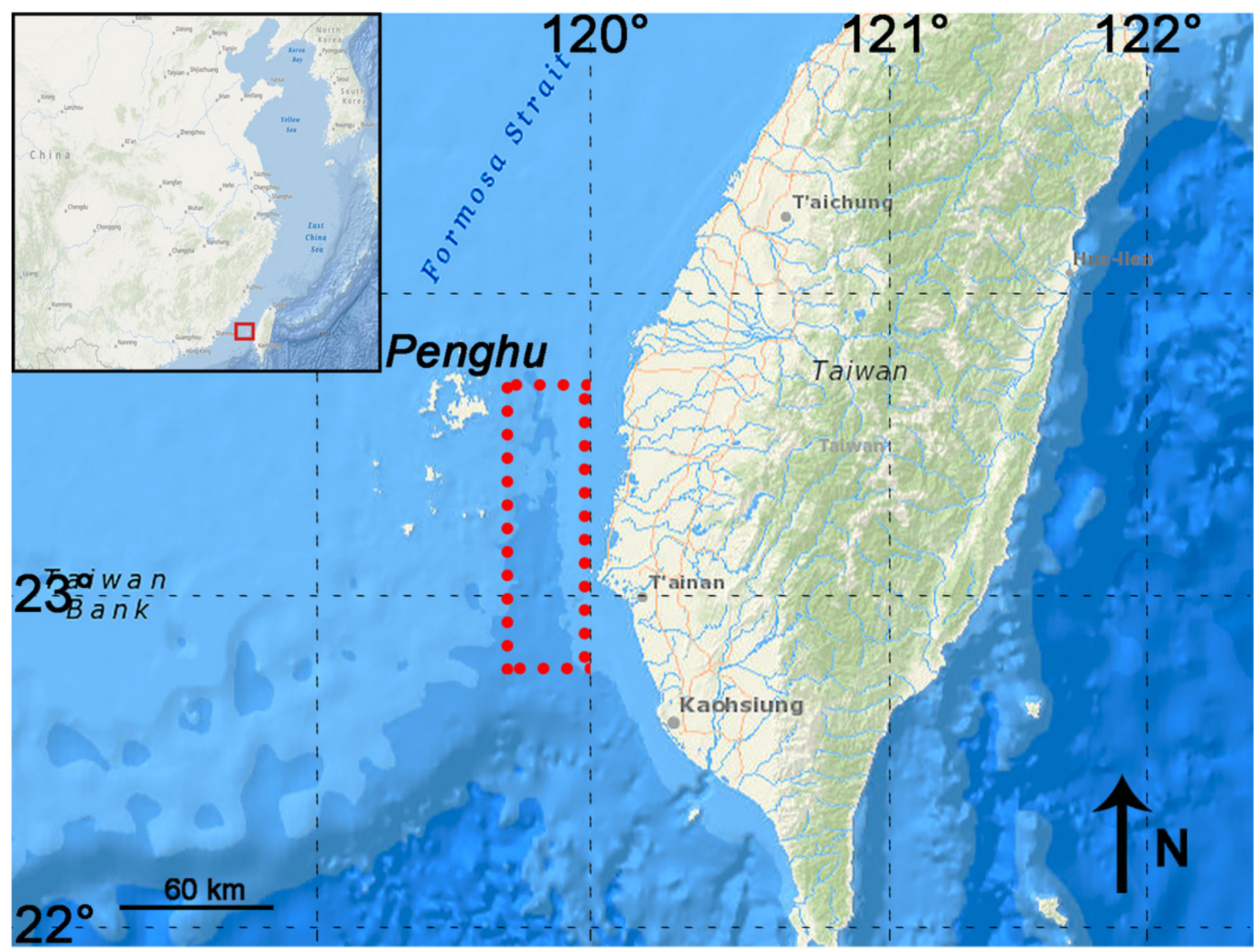




\section{Figure 2}

Images of $P$. huaihoensis specimens deposited at the National Museum of Nature Science (NMNS).

(A) Nine enamel loops complete of the lower left dp4 and erosion at both ends, F027933. (B) All lamellae in wear and the lower right M1 is connected to M2, which is slightly worn and lacks enamel thickness (ET), F020284. (C) Nineteen lamellae of the lower left M3 in buccal view, F051590. (D)(E) The upper right and left M3 with all lamellae in wear and slightly eroded at both ends, F026947. (F) Buccal surface of the lower right M3, F020284. (G) Anterior 2-3 enamel loops confluent on the occlusal surface of lower right M3 from catalog number F020226. (H) Lingual view of the lower right M3, F020248. All scale bars represent $5 \mathrm{~cm}$. 

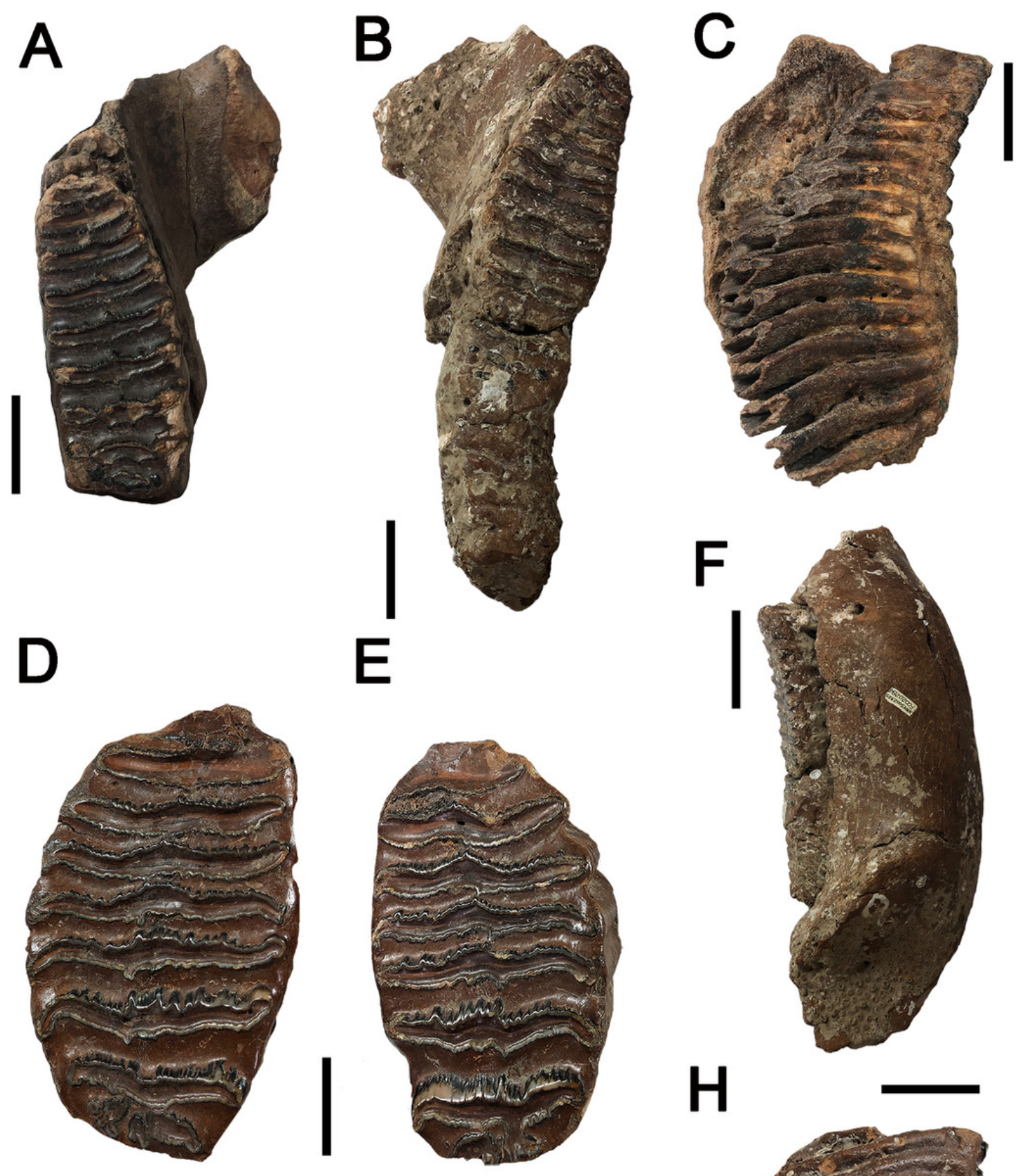

G
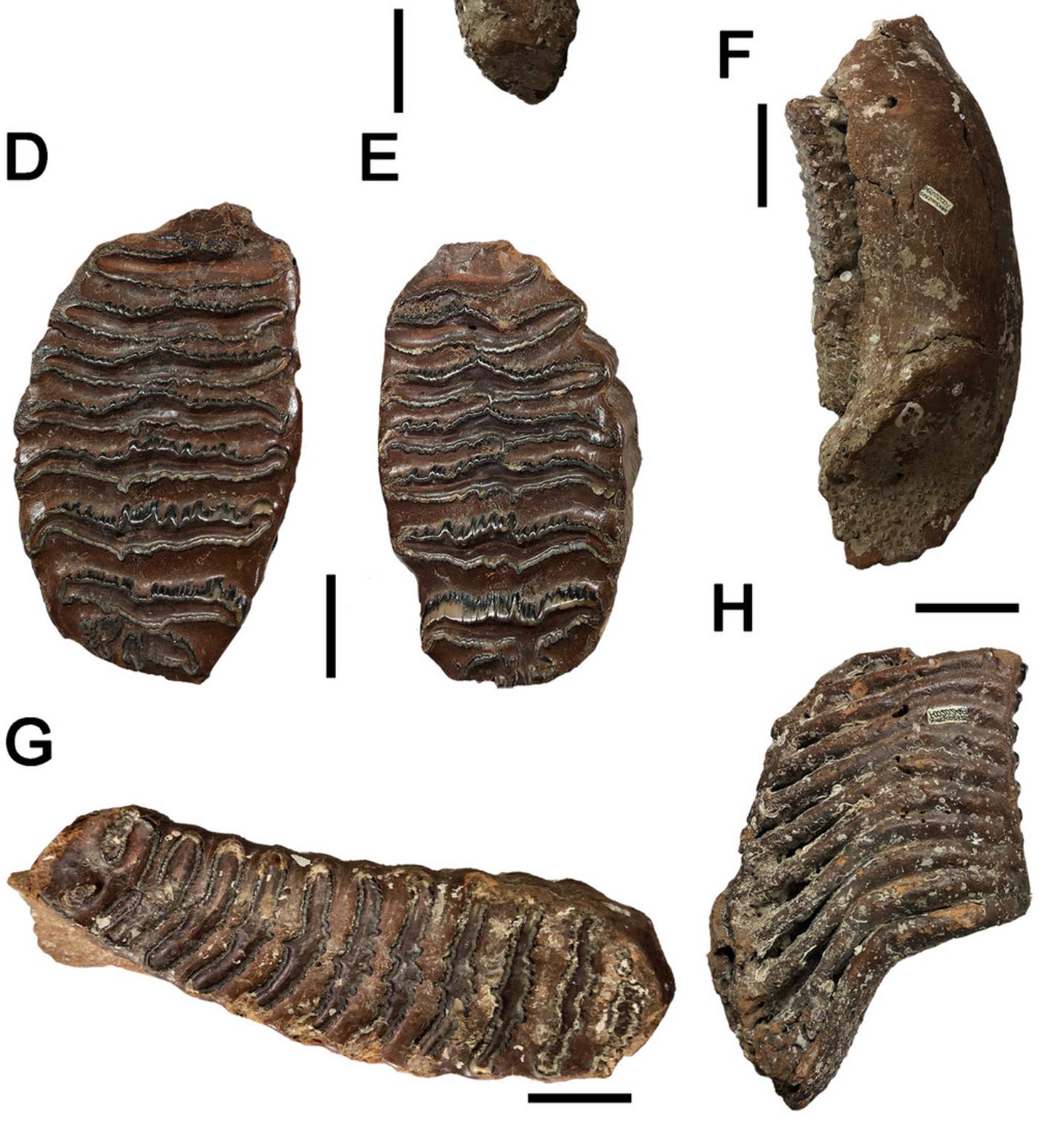
Figure 3

Measurements of an elephant tooth used in this study.

(A) The length of dental material and width were measured. (B) The height of tooth was

taken from the crown apex of the highest plate to the crown base on both the lingual and buccal sides. 
A

socket of previous tooth

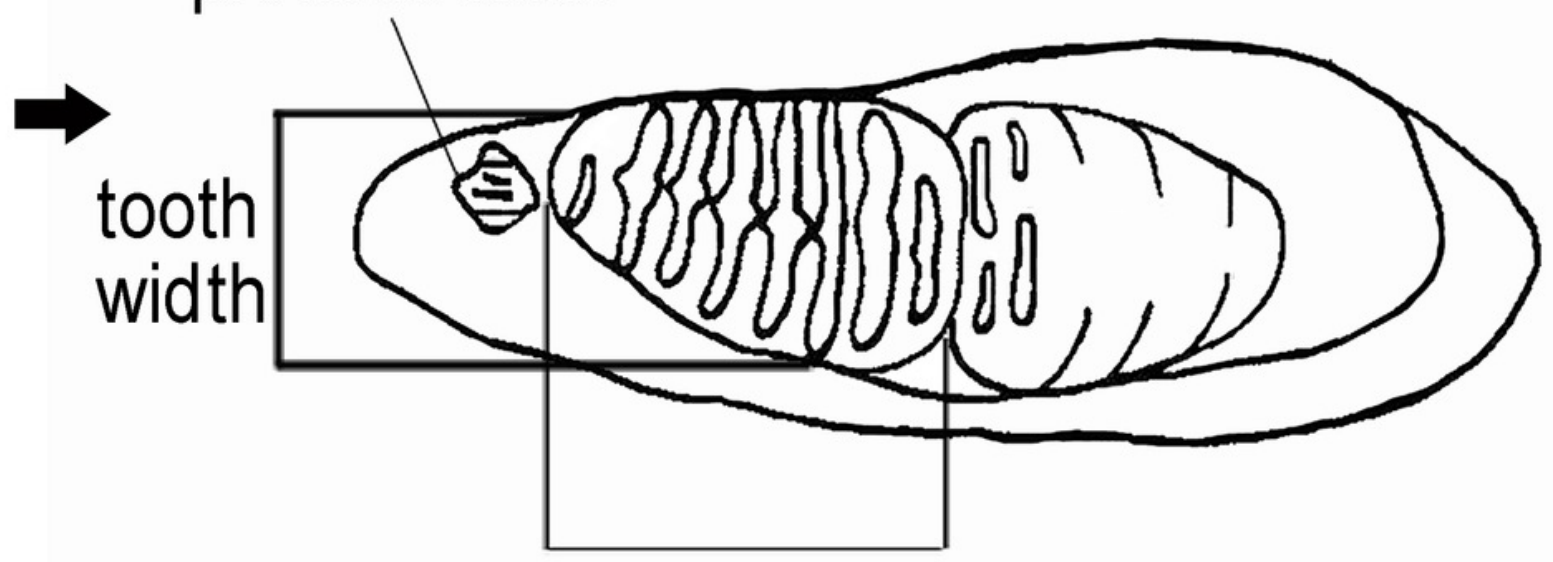

tooth length

B

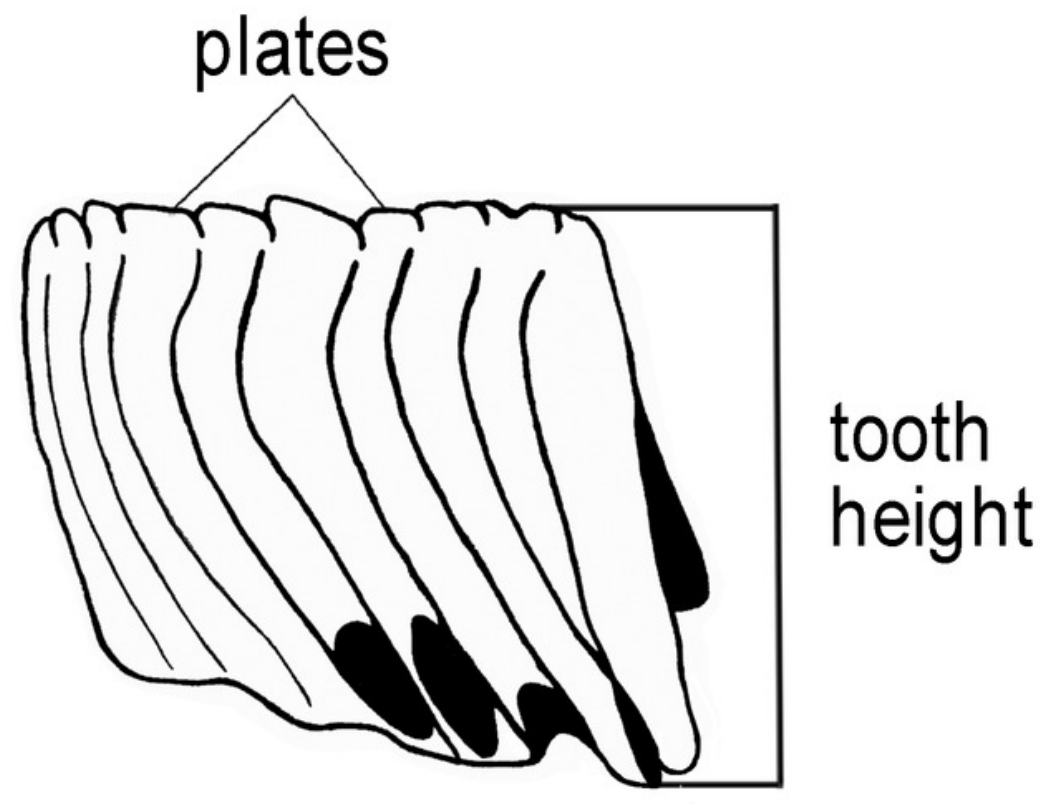




\section{Figure 4}

\section{Definition of age groups I-XXIV.}

I: dp4 all lamellae in wear, M1 slight wear (specimen number: F02793); II: dp4 well worn, approximately 3-4 plates remaining; M1 first 1-2 lamellae in wear (F051613); III: M1 all in wear; M2 worn to enamel of first two lamellae (F044264); IV: M1 first 1-2 enamel loops confluent, M2 slight wear (F020284); V: M1 well worn; M2 more enamel loops showing (F051497); VI: M1 only 5-6 enamel loops left, slight erosion of posterior border; M2 lamellae well formed (F051562); VII: M1 well worn, only three plates remain; M2 slight erosion of anterior edge, 9-10 enamel loops complete (F027950); VIII: M2 first enamel loops confluent (F044271); IX: M1 worn out; M2 well into wear showing lozenges, more lamellae visible (F020247); X: M2 all except last 3 lamellae in wear (F020255); XI: M2 complete, all lamellae in wear, and all enamel loops showing M2 erosion at both ends; M3 lamellae well formed (F027988); XII: M2 all lamellae in wear, 15 enamel loops complete (F026927); XIII: M2 only approximately 8-9 loops remain and erosion at both ends (F020287); XIV: M3 worn to enamel of first lamellae and more enamel loops (F030111); XV: M2 lost; M3 11-12 enamel loops complete (F020278); XVI: M2 worn out; M3 no erosion of anterior border, anterior 1-2 enamel loops confluent (F044257); XVII: M3 only 2 lamellae not in wear (F027320); XVIII: M3 all except last lamellae in wear (F044266); XIX: M3 first 1-2 enamel loops may confluent (F051487); XX-I: M3 erosion at both borders, anterior 2-3 enamel loops confluent (F026942); XX-II: M3 all except last lamellae in wear (F020258); XXI-I: M3 more enamel loops showing, slight erosion of the anterior border (F044270); XXI-II: M3 well worn, first enamel loops may be slightly confluent (F051560); XXII-I: M3 all lamellae in wear, no erosion at both ends (F044268); XXII-II: M3 erosion at both borders, anterior 2-3 enamel loops confluent (F027963); XXIII-I: M3 only five complete enamel loops remain, anterior part broken off (F044261); XXIII-II: anterior third of tooth missing, only five complete lamellae remain 
(F027967); XXIV: M3 only 2-3 loops remain (F051559).

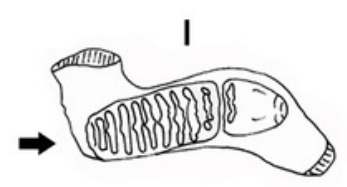

II

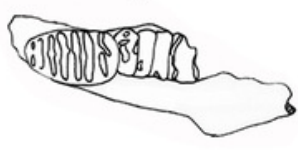

III

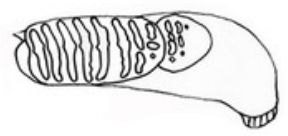

IV

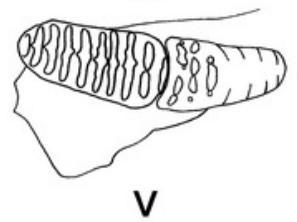

$\mathrm{V}$

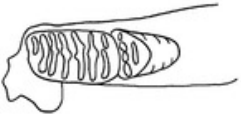

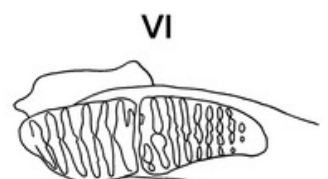

VII
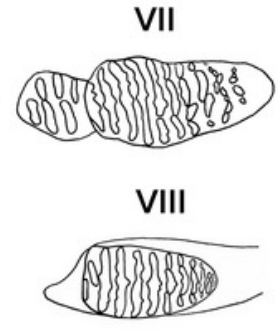

IX
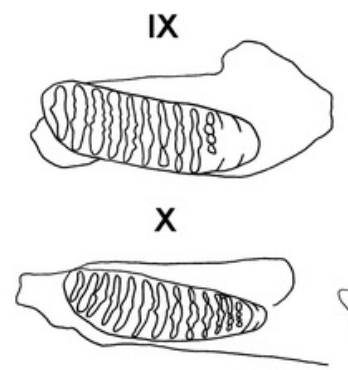

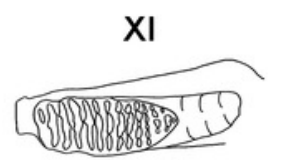

XII

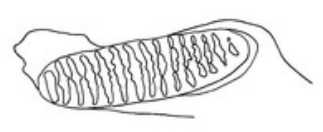

XIII

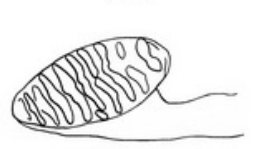

XIV
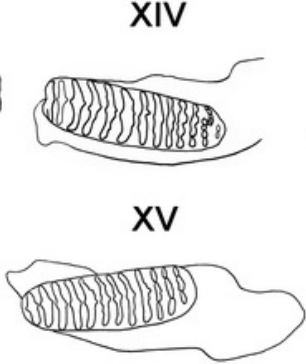
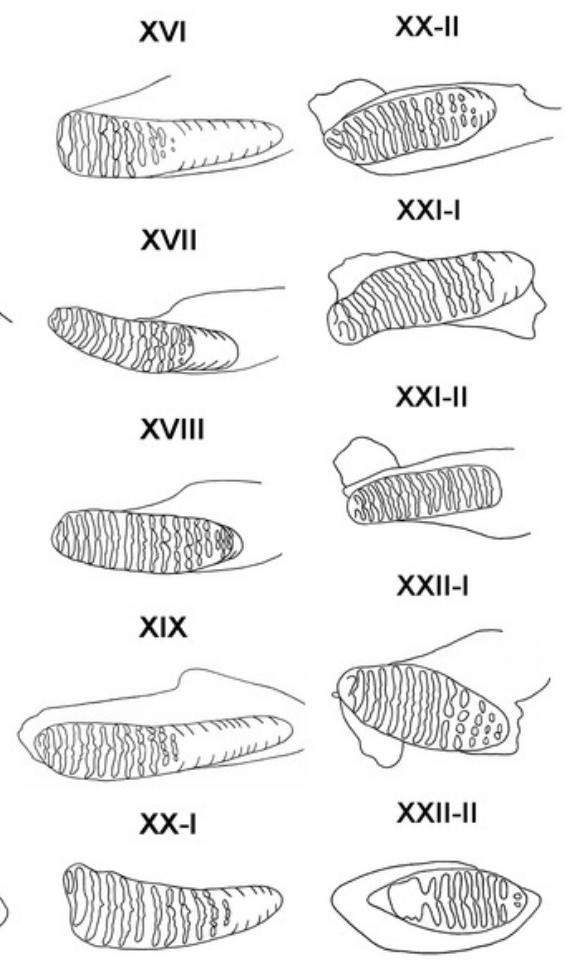

XX-II

XXI-I

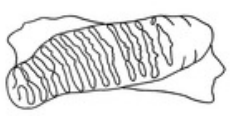

XXI-II

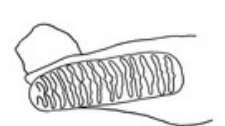

XXII-I

XXIII-I

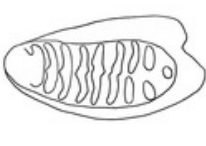

XXIII-II
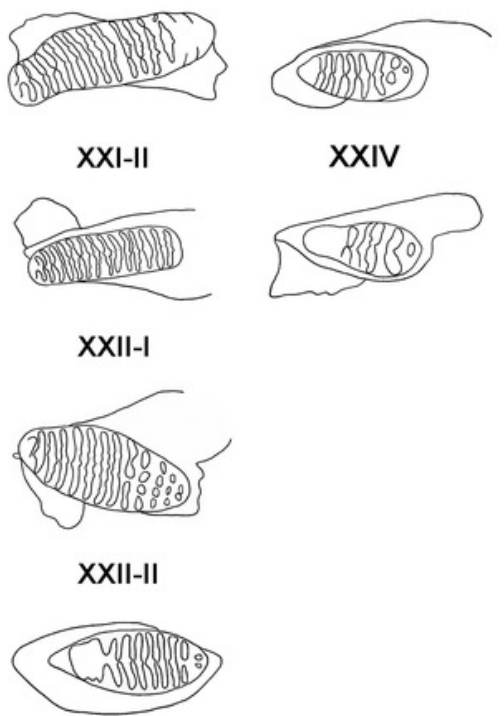


\section{Figure 5}

The relationships of various meristic measurements in the jaws of dp4-M3.

(A) Tooth width and lamellar frequency in the occlusal surface of the upper jaw $(r=-0.558, t$ $=-7.699, p<0.05)$. (B) Tooth width and lamellar frequency in the buccal side of the upper jaw $(r=-0.476, t=-6.201, p<0.05)$. (C) Tooth width and enamel thickness (ET) of the upper jaw $(r=0.531, t=7.179, p<0.05)$. (D) Width and lamellar frequency in the occlusal surface of the lower jaw $(r=-0.649, t=-7.915, p<0.05)$. (E) Width and lamellar frequency in the buccal side of the lower jaw $(r=-0.453, t=-7.523, p<0.05)$. (F) Width and ET of the lower jaw $(r=0.457, t=4.759, p<0.05)$.

A

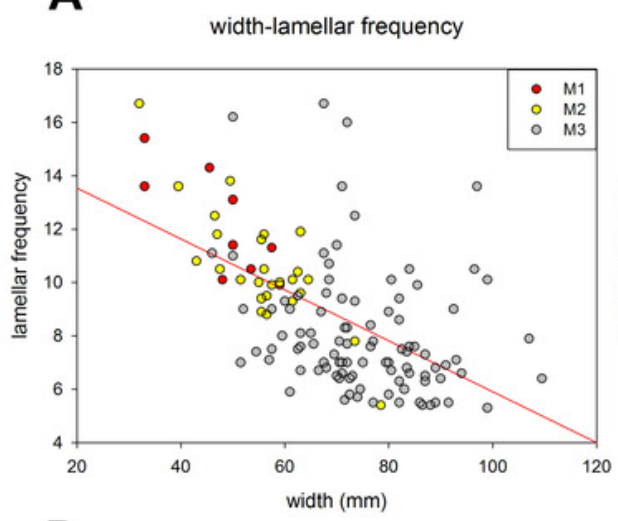

D

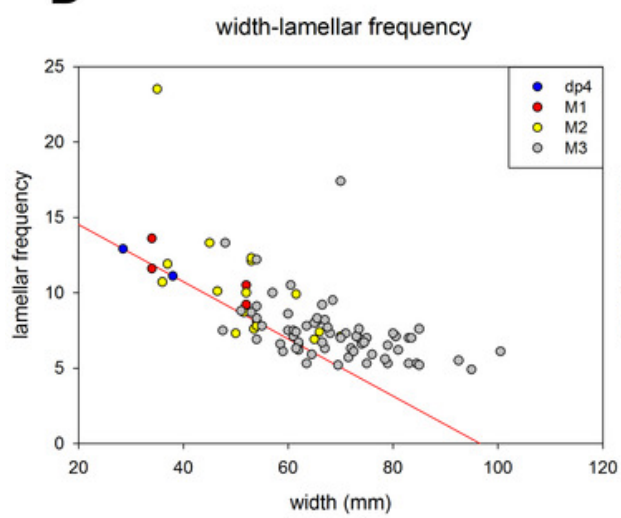

B

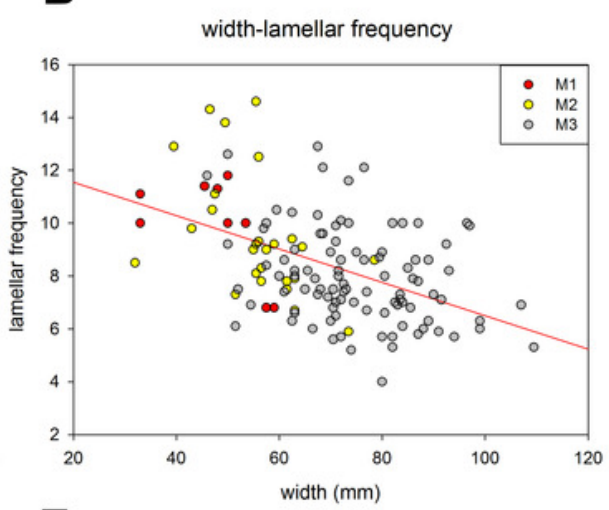

E

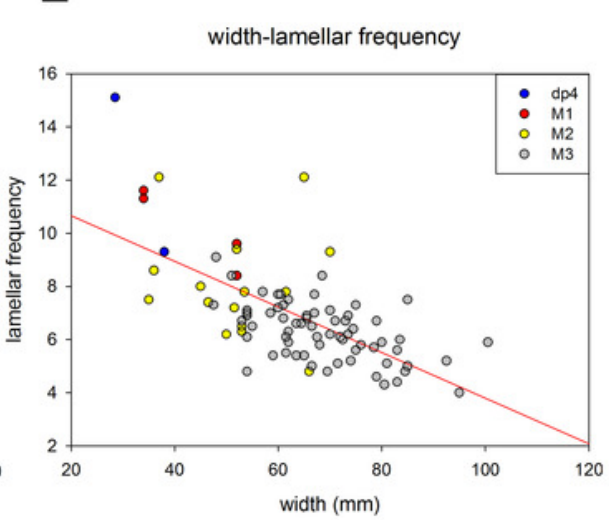

C

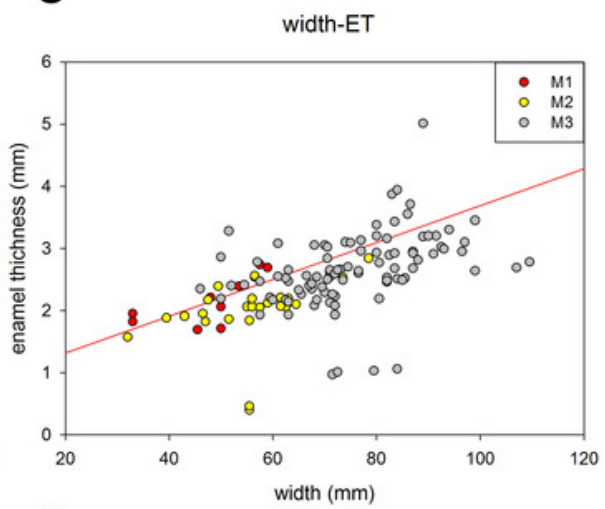

F

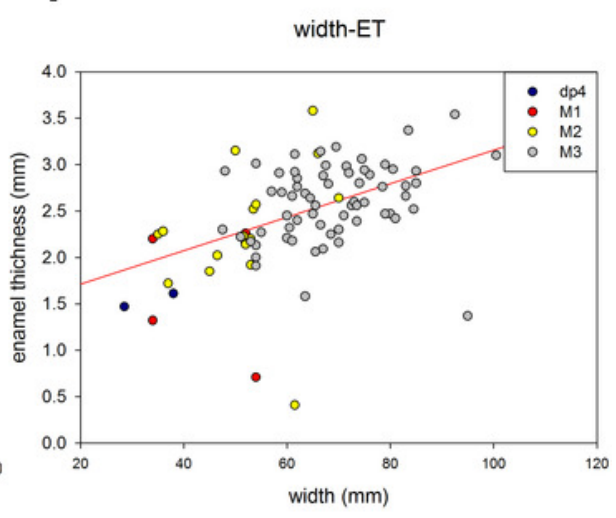


Figure 6

Differences in the relationship of the number of lamellar and age in $P$. huaihoensis and L. africana. Data of $L$. africana are from Laws (1966).

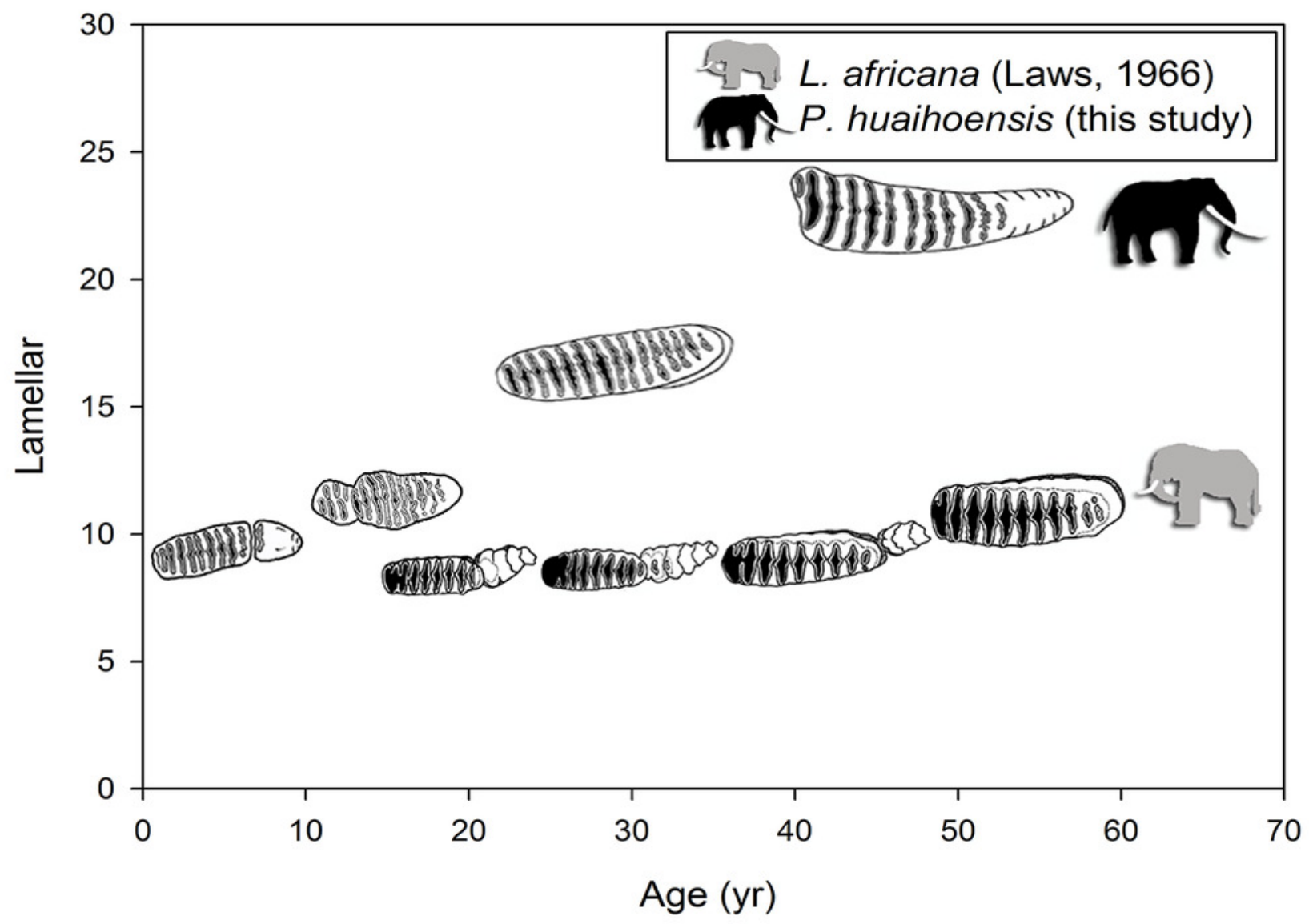


Figure 7

Age distribution of $P$. huaihoensis from Penghu Channel, Taiwan. The frequency (\%) is based on the proportion of specimens ( $n$ ).

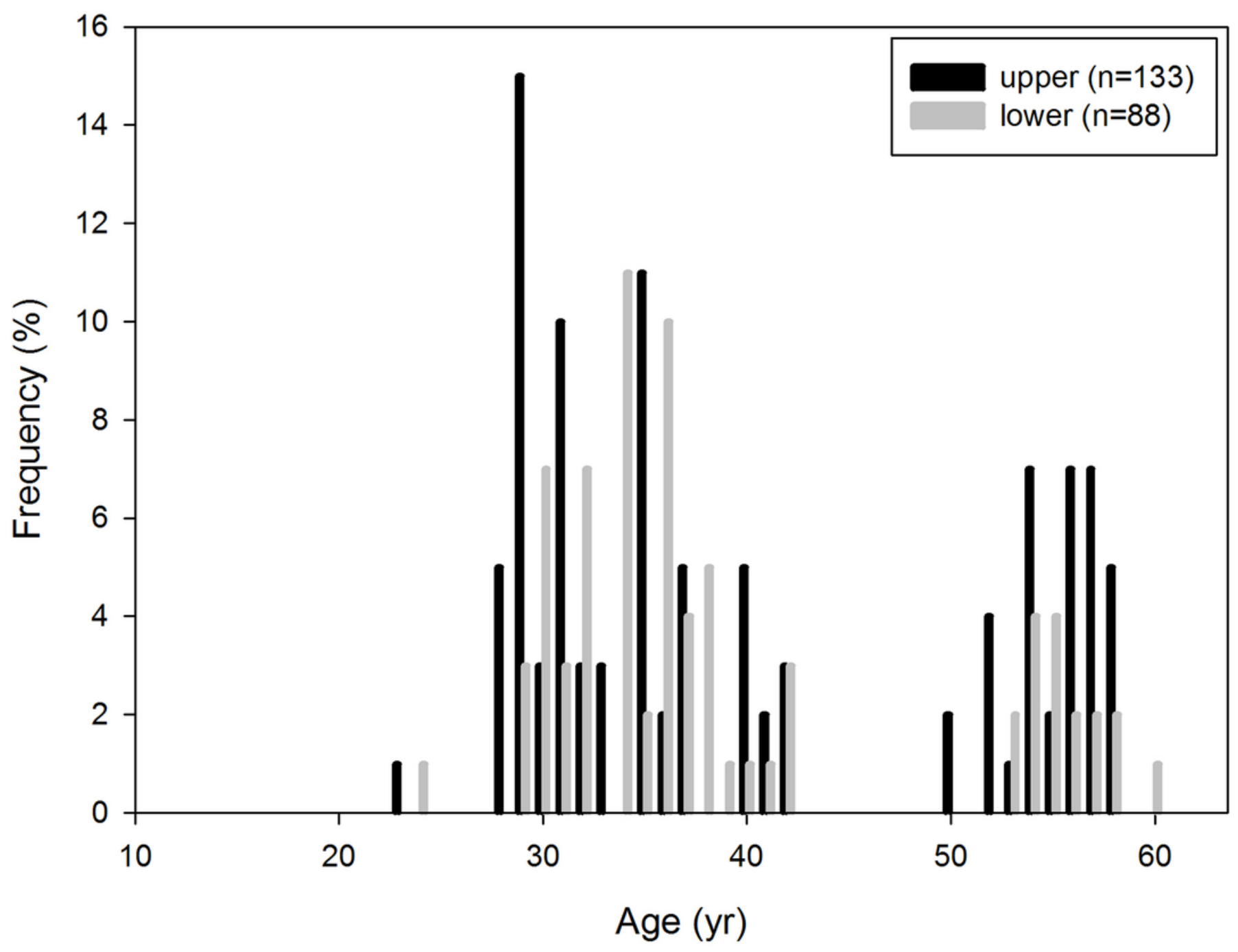


Figure 8

Comparison of the age distribution of $P$. huaihoensis with that of (A) M. primigenius and (B) M. columbi. 
A

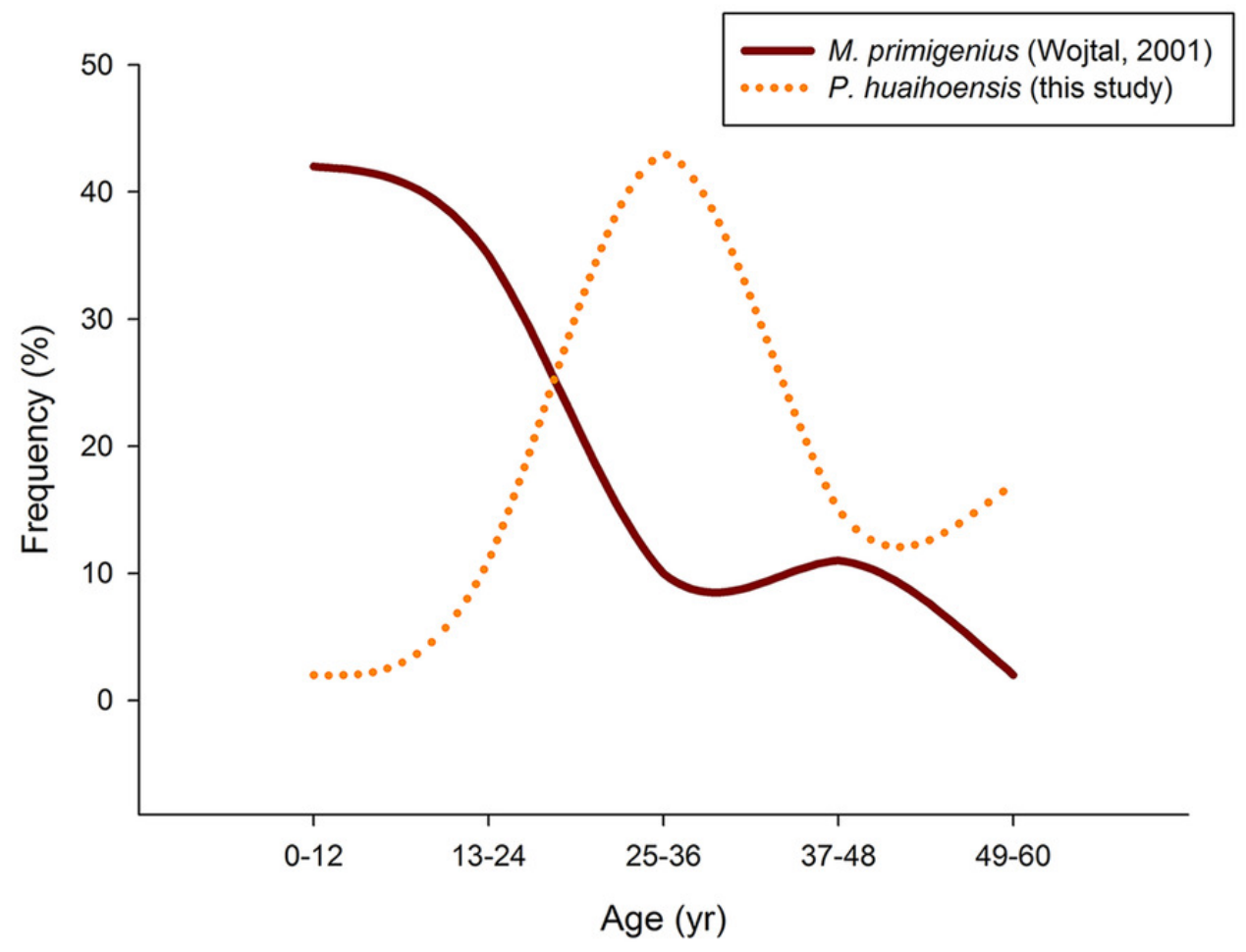

B

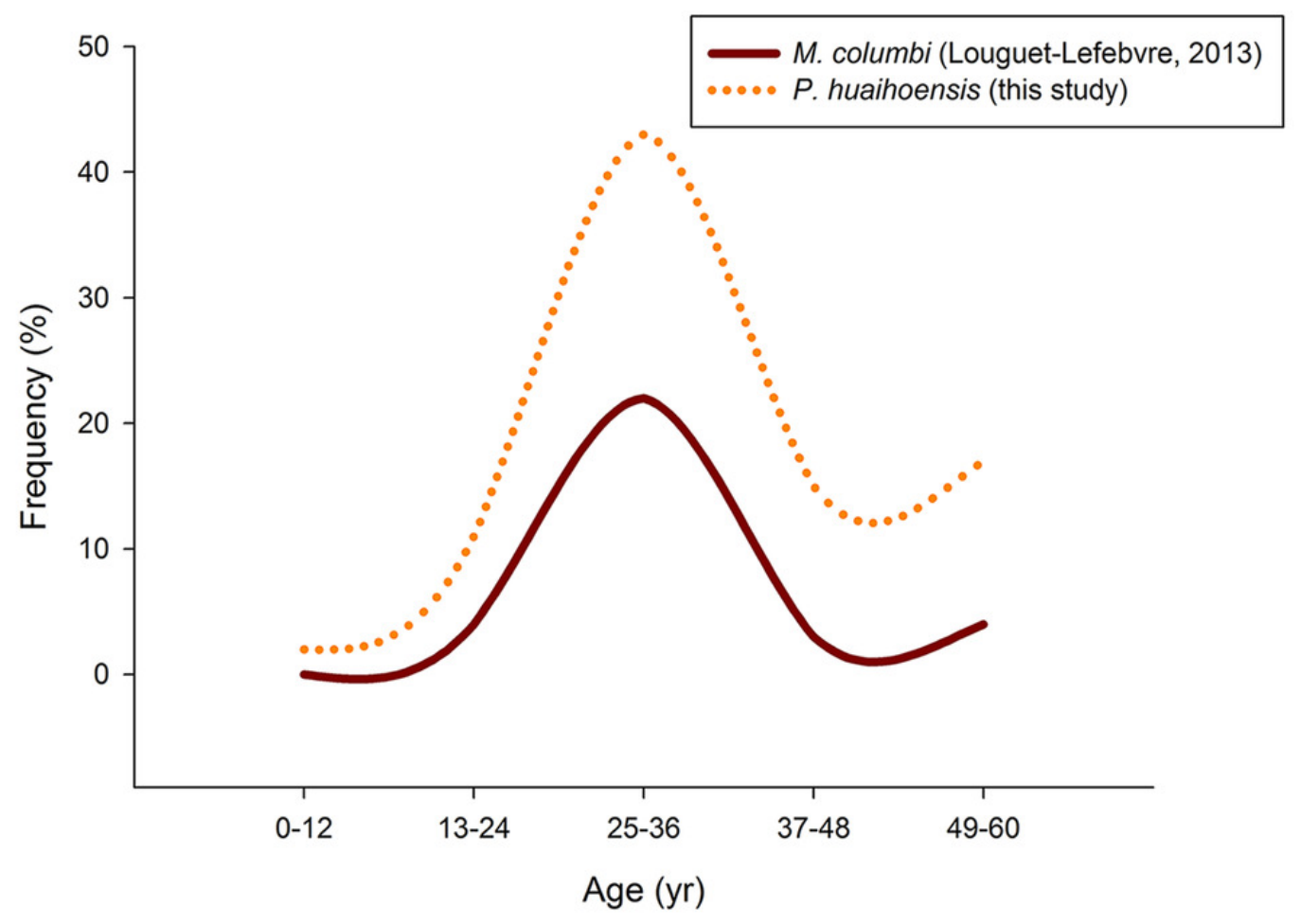




\section{Figure 9}

Postulated migration direction (black arrow) of $P$. huaihoensis.

The species likely originated from northern China (white circle), where fossil records are more abundant. The extension of the record in the Penghu Channel (black rectangle) in the last ice age is currently its southern limit. The current sea depth contour $(-120 \mathrm{~m})$ delineates the ancient coastline during the last ice age. The map is derived from the National Centers for Environmental Information (https://www.ngdc.noaa.gov). 


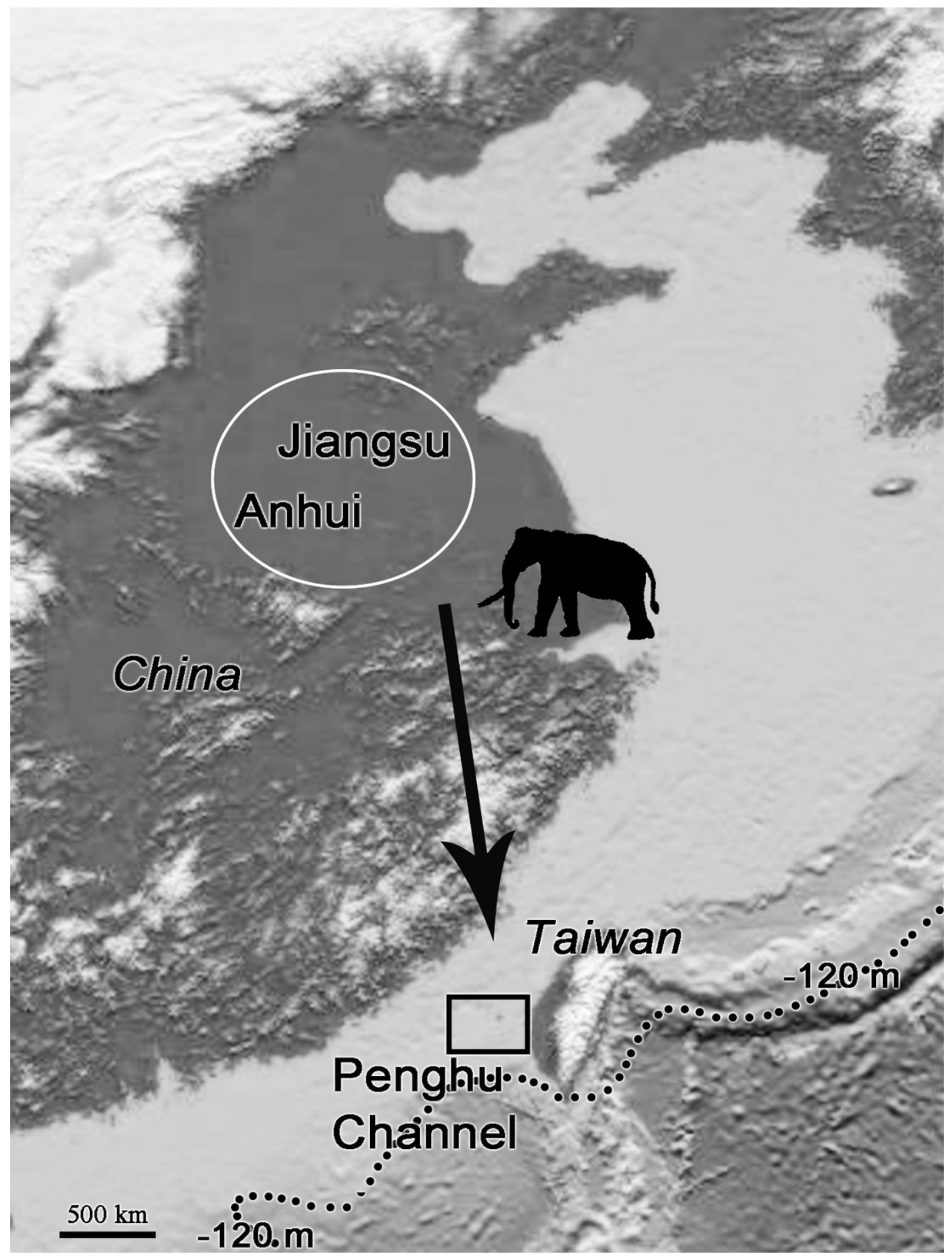




\section{Table $\mathbf{1}$ (on next page)}

Comparison of estimated ages derived from the lower jaw of $P$. huaihoensis and $L$. africana. The positions of the teeth used in Laws (1966) are indicated in parentheses. 


\begin{tabular}{ccccccc}
\hline \multirow{2}{*}{ Tooth position } & \multicolumn{2}{c}{ L. africana (from Laws, 1966) } & \multicolumn{4}{c}{ P. huaihoensis (this study) } \\
\cline { 2 - 6 } & Age groups & No. of lamellae & Age (yrs) & Age groups & No. of lamellae & Age (yrs) \\
\hline dp2 & I-V & 3 & $0-3$ & - & - & - \\
dp3 & VI-X & 7 & $4-13$ & - & - & - \\
dp4 & XI-XV & 9 & $15-24$ & I-IV & 9 & $4-16$ \\
M1 & XVI-XX & 9 & $26-34$ & V-X & 11 & $18-28$ \\
M2 & XXI-XXV & 10 & $36-47$ & XI-XVI & 17 & $32-41$ \\
M3 & XXVI-XXX & 12 & $49-60$ & XVII-XXIV & 22 & $43-57$ \\
\hline
\end{tabular}

1 